\title{
Study of Evaluation Methods of SOEs Manager's Performance for Inhibiting Corruption
}

\author{
Junfang Xia \\ Management School, Jinan University, Guangzhou, China \\ Email: 739971016@qq.com
}

Received 7 September 2015; accepted 13 October 2015; published 16 October 2015

Copyright (C) 2015 by author and Scientific Research Publishing Inc.

This work is licensed under the Creative Commons Attribution International License (CC BY). http://creativecommons.org/licenses/by/4.0/

(c) (i) Open Access

\begin{abstract}
Nowadays, state-owned enterprises in China have been troubled by executives corruption. The one of reasons is inappropriate design of the evaluation methods of SOEs manager's performance, which is the basis of executives compensation program. Then, we explore evaluation methods of SOEs manager's performance, and try to come up with some advises to prevent corruption.
\end{abstract}

\section{Keywords}

\section{Evaluation Methods, SOEs Manager's Performance, Executives Corruption}

\section{Introduction}

Executives of state-owned enterprises (SOEs) that are the affiliation of Chinese government seldom face executive corruption before SOEs reform, when the production and operation of SOEs are planned by government. The enterprises can't make its own managerial decision and service for finishing social goals set by government, which harm the development of SOEs and put them into the loss. Moreover, the managers of SOEs are members of government official; their remuneration depends on their administrative level. So, it is very difficult for them to be corrupt.

Then, SOEs reform conducted since 80s not only helped SOEs get rid of loss, but also developed them to be the leader that played a critical role for the development national economy. However, such great promotion in the scale of national assets seduces managers to behave against the development of SOEs, mainly represented by executives corruption, which is strengthened by the weak supervision of government because of the dual role that SOEs are both enterprise and organization which tie up to Chinese government.

For example, according to China Economic Weekly, the number of SOEs who are fired and investigated for 
corruption total to 124 . They are from the pivotal industry closely related to national economy, such as oil, steal, coal, communication, electricity and war industry, which imply that SOEs have faced executives corruption, such as management override, which leads to a great deal of national asset get lost. Moreover, in April 1st, 2013, State-owned Assets Supervision and Administration Commission (SASAC) issued a five-year plan for anticorruption, which highlighted the supervision to executives of SOEs and the protection to national asset. Therefore, such supervision is very important in the SOEs reform. Nowadays, the supervision to executives of SOEs is exercised mainly through the evaluation system of manager's performance in China. As a government department, SASAC has the responsibility for assessment of manager's performance, preventing managers to act against the goal of maintaining value and increment of state-owned property. However, the evaluation system of manager's performance doesn't play a role in monitor, instead stimulating corruption. Donghua Chen, etc. [1] and Xinyuan Chen, etc. [2] indicated that the fundamental cause of executive corruption in SOEs was inefficiency of compensation contracts. Because executives can't be inspired through conventional market channels, they try only to seek the alternative executive incentive like non-pecuniary compensation, graft, taking bribes, embezzlement as compensation. And Pingli Li and Chao Ning [3] cleared that evaluation of manager's performance is equal to compensation program. The evaluation system of manager's performance should include three links: the design of index system, the selection of standards and determination of targets. And the compensation program is based on the evaluation results. That is, management compensation contract depends on the evaluation of manager's performance. Therefore, deepening reform of compensation contract and establishing performance oriented compensation program are good for inhibiting corruption [4].

Thus, we seek to explore the evaluation system of SOEs manager's performance to prevent corruption and protect national assets.

\section{Brief Introduction to Evaluation Methods of SOEs Manager's Performance}

Business Performance Assessment system is a valuation of achievement of goals set for SOEs during a time. People have different views on performance appraisal. The reform of shareholder structure in listed companies has improved effects of corporate governance, but China's system background and the unfulfilled SOEs reforms bring companies the issue of insider control caused by owner absence and unreasonable structure of holders like one share being overwhelming big. It is very difficult for board to monitor management, and the board controlled by managers makes a decision harm company but benefit themselves associating with these managers. Therefore, the supervision is enforced by SASAC, which views company operation by evaluating executives, aiming to maintain value and increment of state-owned property, meanwhile to examine whether SOEs executives fulfill social responsibility.

Nowadays, the assessment to central SOEs' performance is enforced by SASAC according to The Evaluation Methods of Central Enterprises' Manager's Performance implemented since January 1st, 2010, which is also the basis of the assessment to SOEs' performance on local level. Here are the three parts of it as follows.

The first part is the draw of indicators for performance appraisal, including the indicators of both annual business performance and tenure performance. Annual business performance indicators including basic index and classification index: basic indicators including Total Annual Profits and Economic Value Added, classification index is determined by SASAC according to industry characteristics, in view of "short board" of enterprise management, and combined with the comprehensive consider reflecting enterprise management level, technical innovation investment and risk control ability. Tenure business performance indicators also includes the basic indicators and classification indicators: basic indicators include value of state-owned assets and MBRG of three-year term, classification indicators are made according to the enterprise industry characteristics, comprehensive considering the ability of enterprise technology innovation resource saving and environment protection, sustainable development and core competence factors. The specific indicators are drawn in the liability statement.

Secondly, it is about inspection standards. The Evaluation Methods of Central Enterprises' Manager's Performance use the budget method as evaluation criteria, require the target submitted by central SOEs in accordance with the inspection requirements and matching with development planning and actual situation, as well as international and domestic advanced level in the similar industry. On the selection of the target, SACAC have emphasized and encouraged the performance assessing in the light of the same industry of international and domestic advanced level.

The last one is scoring method. The scoring method in the evaluation methods gives each index a basic score. 
Then, it keeps compare the comparison results that got from the comparison between the actual performance and goal set before with the related regulation to determine the degree of adding or subtracting points on the basis of the basic points.

Xiuli Pan [5] pointed to two obstacles in executive incentives: the first one is incentive deficiency, the SOEs executive remuneration has composed of salaries and bonus for a long time. The payment is very low in general, and most of them are pecuniary compensation. The evaluation system of SOEs manager's performance neither reflect efforts of executives, nor reveal realization of corporate strategy, especially for SOEs. Because compensation is close to position level but has little to do with managers' efforts, which cause managers acquire nonpecuniary compensation to compensate their loss. The second one is inappropriate executive incentive, the manager compensation in enterprise with loss is higher than that in profitable business. Moreover, some operators only take emphasis on short-time benefits for fulfilling compulsory objective that set by SASAC, which hide their motivation of pursuing self-interesting.

In short, The Evaluation Methods of Central Enterprises' Manager's Performance and its ramification, the one of local SOEs adopted indexes of accounting performance. It has little to do with the measures based on market performance. These indexes are the valuation of state-owned enterprise comprehensive performance, unable to measure manager's performance. In other words, the current methods have low accuracy and sensitivity in reflecting manager's performance, and has limitation in executive incentives, which raise the motivation of corruption for SOE executives.

\section{Suggestion for Evaluation Methods of SOEs Manager's Performance}

To stop executives corruption and improve evaluation methods of SOEs manager's performance, we come up with five advices. Here are these suggestions.

\subsection{Reflecting Manager's Performance Accurately}

Yansong Qian [6] suggested that enterprise performance index is comprehensive one influenced by various factors like macro-economic situation, industry characteristics, company features and power, manager's efforts and ability. manager's performance is his contribution to company, and the overall impact on survival and development of enterprises by manager's behavior depending on their knowledge, capacity, experience and their own resources. Some scholars pointed that the measures for assessing performance of SOEs managers is replaced by the one measured enterprise performance, therefore there are difficulties in reflecting manager's performance exactly. And it is not equal for managers to signing the compensation contract based on these current measures, as their compensation is not equal to their efforts. When managers feel that they can't be pay equivalently, they will seek to other approaches to make up for their efforts, such as illegal operation of national assets, encroachment, embezzlement, excessive transaction management, graft and bribe-taking, extra non-pecuniary compensation, and construction of their own institution by stealing corporate resources. So it is very necessary to set the measures of manager's performance that links closely with their efforts.

\subsection{Choosing Measures of Long-Term Performances and Avoiding Absolute Index}

The measures of long-term performances are the one leading managers to consider long-term benefits and avoid short-term behaviors. Compared with those taking future benefits into account, managers who are short-sighted are more motivated to taking corruption. Those having long-term consideration don't choose corruption that harms their reputation because of the consideration of future career. However, short-sighted managers just addicted to the temporary benefits, trying to take this chance to benefit themselves, regardless of the bad impacts on firm's prospect. Qing Sun and Hongzhen Zhang [7] suggest that profit target is the one of accounting indexes, also the short-term performance one, which be used to measure firm's current operation. In addition, account measures reflect historical data. When corporate governance is weak in monitoring and controlling managers, profit targets isn't efficient in evaluating manager's performance and lag behind operation. Absolute index is the tool assessing manager by some absolute numbers, which taking emphasis on improving amount, causing central enterprise executives pursuing only amount but overlook quality, such as unsustainable rapid expansion. To achieve the goal of absolute index, some managers ignore operation quality, and more likely to acquire extra compensation and rewards at the cost of long interests. This proves that long-term indexes help to inhibit cor- 
ruption, but absolute index. So we can use net Cash Guarantee Ratio and EVA Rate of Return to replace Profit and EVA, which can reflect the operating truth quality and value of enterprise, and improve the comparability between different firms' performance. Moreover it is necessary to take Staff Growth and Rate of Capital ProfitTaxation to increase the awareness of non-financial indicators and social responsibility.

\subsection{Taking SOE's Social Goals into the Evaluation Methods}

Chunbo Wu (2005) [8] thought that unlike other companies, SOEs also bear the social responsibility and government tasks. The methods for assessing performance of SOEs managers are limited to indicators of manager's performance, which can't reflect the social responsibilities bear by state-owned enterprises. In the situation, managers' behavior object to employment, social benefit, some policies, the evaluation methods of SOEs manager's performance doesn't balance economic index and non-economic index. In order to achieve policy goals like guaranteeing employment, increasing tax, maintaining stability, SOEs are bound to put part resources used in the production and operation into achieving these goals, but damaging to the performance of SOEs. Since performance assessment is the evaluation of manager's performance, it is not fair for executives bearing a large amount of social goals to take the methods confined to operator performance indicators. They want to improve performance, but such goals force them to behave harming corporate performance, and be evaluated as bad leaders. In this case, executives will be likely to choose corruption to pursue private interests. Therefore, it is necessary to bring social responsibility into the evaluation methods of SOEs manager's performance.

\subsection{Considering Features of Enterprises and Industry Difference}

Nowadays, the evaluation of SOEs manager's performance mainly use basic indicators. And the assessment system whose body is basic indexes is relatively single. Imagining that using the unified index for all SOEs without considering enterprise features, it is clear that managers don't have incentive to run a company, because do good is same with do not good. For example, while the target of central SOEs of monopoly industry should be to keep and rise up asset value, SOEs in competitive industries should pay more attention to profitability. If measuring performance of these two kinds of companies by the same methods, we can't get the objective and fair result. And some classification indexes seemingly taking the differences of industries and companies into account just give the basic guiding ideology, not the interpretation of specific items and instructive, which offers executives spaces to seek private interests by corruption. So we need to consider features of enterprises and industry difference when evaluating performance. We should take the different methods to assess SOEs of different degree of monopoly. Because the higher the degree of market monopoly, the lower the difficulty of acquiring the enterprise profit. We also can distinguish SOEs according to industry differences. While marketization is higher in the industry with high profit, SOEs of low profit industry face with large excessive investment and vicious competition. Then, using market indicators to measure enterprise performance is invalid.

\subsection{Setting Reasonable Evaluation Standard}

Bing Wang [9] thought that establishing reasonable evaluation standards is the emphasis and difficulty in constructing the performance evaluation system. The evaluation methods of SOEs manager's performance adopts budget, enforced according to international and domestic advanced level in the same industry. However, due to the special regime in our country, one share being overwhelming big and interior agent control caused by owner absence, it is impractical to compare SOEs in our country with advanced enterprises of developed industry in the developed market. And ignoring the conditions faced by SOEs and adopting high appraisal standards, the managers will lose their confidence and motivation to run a company. Since it is impossible to achieve high standard whatever they do, managers had better to put energies into other places, to meet their own private interest. So we should think that whether it is practical to choose evaluation methods. So, when assessing the performance through benchmarking tool, we should deal with the performance value of a group of comparative excellent enterprises to eliminate the differences in firms' basic condition, modifying evaluation methods measuring output through the improved performance.

\section{Conclusion}

Thanks for SOEs reform, SOEs have got great development, and the scale of state-owned assets expands rapidly. 
But the rapid raise on the revenue of SOEs causes executives corruption to the extent. In recent years, a large disclosure of executive corruption of SOEs has a serious impact on the state and society, for example, the governments' credibility is descending. Such corruption has also caused the huge loss of state-owned assets, damaging national economy. It is very urgent to decrease and even eliminate corruption. At present, the supervision on SOEs is conducted by SASAC. The one of important measures is the appraisal on performance of SOEs operators. However, the evaluation methods of SOEs manager's performance cannot evaluate executives' performance effectively, and can be limited to inhibition on corruption. Therefore, in this paper, we study the appraisal on performance of SOEs operators and come up to some measures to improve the evaluation methods of SOEs manager's performance to prevent corruption. These measures include reflecting manager's performance accurately, choosing measures of long-term performances and avoiding absolute index, taking SOE's social goals into the evaluation methods, considering features of enterprises and industry difference, and setting reasonable evaluation standard.

\section{Researches and Prospects}

At present, the academic research on executive corruption has focused on the reason of corruption of SOEs executives, seldom involving the research to the measures inhibiting state executive corruption. And existing researches on these measures are concentrated on the system of nation or company, such as Chinese special state institution, equity structure of SOEs, the dual roles of executives and so on. The research on the concrete measures to decline corruption basing on the central enterprise operator performance evaluation methods is few. We think that future research can follow the point of view, like studying the impact of the specific performance index, criteria of assessment, scoring methods on corruption, with the consideration on industries difference and firms' characters.

\section{References}

[1] Chen, D.H., Chen, X.Y. and Wan, H.L. (2005) The Control of Remuneration and Vocational Consumption in SOEs. Economic Research Journal, No. 2, 92-101.

[2] Chen, X.Y., Chen, D.H. and Wan, H.L. (2009) Regional Differences, Remuneration Regulation, Executives Corruption. Management World, 25, 130-142.

[3] Li, P.L. and Ning, C. (2000) A Discussion about Manager’s Performance. Accounting Research, No. 5, 22-27.

[4] Xu, X.X. (2012) A Analysis of Research Frontier Executives Corruption. Foreign Economics \& Management, 34, 73-80.

[5] Pan, X.L. (2002) An Evaluation Criteria of Business Performance and Manager's Compensation Contract. Accounting Research, No. 7, 31-35.

[6] Qian, Y.S. (2010) A Research on Assessment Methods of State-Owned Monopoly Enterprises. Finance and Trade Research, No. 4, 137-141.

[7] Sun, Q. and Zhang, H.Z. (2012) A Research on Assessment Methods of Principal's Performance of Chinese Central State-Owned Enterprises. Proceedings of the 18th Annual Financial Year, Nanning, 10-11 November 2012, 1-8.

[8] Wu, C.B. (2005) A Review on Assessment Methods of Principal's Performance of Chinese State-Owned Enterprises. Economic Theory and Business Management, No. 2, 40-42.

[9] Wang, B. (2008) Performance Evaluation System of Chinese State-Owned Enterprises: A Review and Reflection. Accounting Research, No. 11, 21-28. 